\title{
Electrophysiological and behavioural responses of Ips typographus (L.) to trans-4-thujanol-a host tree volatile compound
}

\author{
Laima Blažytè-Čereškiené ${ }^{1} \cdot$ Violeta Apšegaitè ${ }^{1} \cdot$ Sandra Radžiutè $^{1}$. \\ Raimondas Mozūraitis ${ }^{1} \cdot$ Vincas Būda $^{1}$ • Dalẻ Pečiulyté ${ }^{2}$
}

Received: 1 October 2014 / Accepted: 5 June 2015 / Published online: 4 July 2015

(C) The Author(s) 2015. This article is published with open access at Springerlink.com

\begin{abstract}
- Key message Spruce trees emit significant amounts of trans-4-thujanol, but the amount of this compound in bark decreases with tree age. Trans-4-thujanol acts as an efficient repellent for the bark beetle Ips typographus.

- Context The spruce bark beetle, Ips typographus, is an economically significant pest of Norway spruce (Picea abies) that preferentially infests and kills old trees.

- Aims We looked for spruce volatiles that were perceivable by I. typographus and that differed as the host tree aged.

- Methods Bark beetles were collected in the wild. Bark samples from spruce trees of different age were hydrodistilled. Gas chromatography-electroantennogram detection (GC-EAD) was used to identify which compounds induced beetle olfactory responses. These were identified by gas chromatography-mass spectrometry
\end{abstract}

\section{Handling Editor: Aurelien Salle}

Contribution of the co-authors Laima Blažytė-Čereškienè conceived the study, performed electrophysiological and behavioural studies, analysed the data, and wrote the paper. Violeta Apšegaite performed chemical analysis, and wrote the paper. Sandra Radžiute contributed to the electrophysiological and behavioural studies, and to writing the paper. Raimondas Mozūraitis contributed to chemical analysis, and performing identification of compounds. Dalè Pečiulyte collected material, contributed to data analysis and writing the paper. Vincas Būda conceived the study, co-wrote the Introduction and Discussion, interpreted the results and coordinated the research project.

Laima Blažytė-Čereškienè

blazyte@ekoi.lt

1 Institute of Ecology, Nature Research Centre, Akademijos St. 2, 08412 Vilnius, Lithuania

2 Institute of Botany, Nature Research Centre, Žaliujų ežerų St. 49, 08412 Vilnius, Lithuania
(GC-MS). Behavioural responses of bark beetles were tested using a Y-tube olfactometer.

- Results Several EAD peaks were recorded, of which trans4-thujanol was consistently active and could be identified chemically unequivocally. The antennae of I. typographus females responded to a lower dosage of the compound than males, but both sexes were repelled by it. The bark of 10 year-old spruce trees contained 3 times more trans-4thujanol than that of 35- 40-year-old trees, 27 times more than that of 70- to 80-year-old trees, and 200 times more than that of 120-year-old trees.

- Conclusions Trans-4-thujanol is a bioactive compound in Norway spruce bark that varies in amount with tree age and affects spruce bark beetle behaviour under laboratory conditions. It is suggested that trans-4-thujanol might play a role in both spruce tree defence and tree choice by beetles.

Keywords Bark beetle $\cdot$ Picea abies - Spruce $\cdot$ GC-EAD . Volatile organic compounds · trans-4-thujanol $\cdot(E)$-sabinene hydrate $\cdot$ Norway spruce $\cdot$ Host plant $\cdot$ Antennal response $\cdot$ Behaviour · GC-MS

\section{Introduction}

The bark beetle, Ips typographus (L., 1758) (Coleoptera, Scolytidae) is one of the most significant pests of Norway spruce [Picea abies (L.) Karst.]; it can destroy large numbers of mature trees and cause substantial economic losses (e.g. Mezei et al. 2014; Wermelinger 2004). The colonisation of spruce trees is initiated by pioneer I. typographus males. After excavation of nuptial chambers, they release an aggregation pheromone that attracts both female and male conspecifics. This triggers a mass attack on a selected tree (Byers 1989; 2004). Small populations of I. typographus colonising 
weakened host trees can increase dramatically to epidemic levels, usually after windstorms or extended periods of drought, destroying large areas of Norway spruce forest (Långström et al. 2009; Wermelinger 2004).

Volatiles released by the host plant play an important role when pioneer bark beetles search for a host tree (Andersson 2012; Erbilgin et al. 2007). Ips typographus can perceive at least 18 compounds emitted by its host plant (Kalinová et al. 2014). Electrophysiological recordings from individual olfactory sensilla on I. typographus antennae indicate that approximately $42 \%$ of olfactory receptor neuron cells are specialised for pheromone perception, $35 \%$ for perceiving host-plant compounds, and at least $23 \%$ for detecting non-host-plant compounds (Andersson et al. 2009). Behavioural assays have demonstrated that several non-host compounds can inhibit I. typographus beetle attraction to the pheromone (Zhang et al. 1999; Zhang and Schlyter 2003). Hence, volatiles released both by host- and non-host-plants are of utmost importance when beetles search for a host tree (Zhang and Schlyter 2004).

Many organic plant-released compounds act either as pheromone synergists or antagonists to insect herbivores (e.g. Byers 1989; 2004; Landolt and Phillips 1997). For I. typographus for example, $\alpha$-pinene-the predominant monoterpene in Norway spruce - enhances the attractiveness of the aggregation pheromone (Erbilgin et al. 2007; Jakuš and Blaženec 2003). Conversely, 1,8-cineole acts as an antagonist inhibiting attraction to the aggregation pheromone (Andersson et al. 2010). A field survey indicated that trees that were attacked but not colonised during an outbreak exhibited a greater content of 1,8-cineole than successfully colonised trees (Schiebe et al. 2012), suggesting the involvement of this compound in tree resistance. The question arises whether 1,8-cineole is the only spruce volatile compound potentially involved in resistance mechanisms or whether other similarly acting compounds are produced and released by spruce trees.

Some volatile plant secondary metabolites sensed by bark beetles remain unknown, as proved by electrophysiological analysis of beetle receptor neurons in olfactory sensilla: it is still not known what substances approximately $24 \%$ of receptor cells respond to (Andersson et al. 2009). Ips typographus preferentially infest old (over 100 years) and large (Becker and Schröter 2000; Zolubas et al. 2009) spruce trees. To discriminate trees suitable for colonization, bark beetles rely on several stimuli, probably including host volatile compounds. Hence, comparative analysis of volatiles emitted by old and young spruce trees could lead to identification and use of some of these compounds in bark beetle control programmes. The objective of the present study was to find spruce treeproduced volatiles to which I. typographus beetles respond and that vary in production as the plant ages. Knowledge of spruce tree volatile compounds that affect the behaviour of
I. typographus beetles, in particular those that act as antagonists of attraction, may have important applications, e.g., for the use of olfactory stimuli in integrated forest protection against bark beetles.

\section{Materials and Methods}

\subsection{Insects}

The I. typographus adults used for analysis were obtained from pheromone (commercial attractant Ipsodor, Chemipan, Warsaw, Poland) multi-funnel traps hung in forest fresh clearcuttings or were collected under the bark of naturally attacked Norway spruce trap-trees from April to September in 2011 and 2012 , in Užtrakis forest $\left(54^{\circ} 35 \mathrm{~N} ; 24^{\circ} 57 \mathrm{E}\right)$, Trakai district, Lithuania. The beetles were selected randomly for the bioassay. Live beetles (for antennal recordings and behavioural assays) were maintained at room temperature (ca. $23^{\circ} \mathrm{C}$ ) in a glass container $(28 \mathrm{~L})$ with spruce bark chips. The sexes were separated based on differences in the density of bristles on the pronotum and size differences of the frontal tubercle and third elytral spine (Schlyter and Cederholm 1981). To ensure correct sexing, the beetles were dissected after the experiments.

\subsection{Bark sample collection}

Norway spruce bark was collected in Sužionys forest $\left(54^{\circ} 58\right.$ $55^{\circ} 02 \mathrm{~N} ; 25^{\circ} 27-25^{\circ} 30 \mathrm{E}$ ) in Vilnius district, Lithuania. In August-September 2010 and in April 2011, trees selected randomly from each of the four populations of 10- $(N=9)$, 35- to 40 - $(N=5), 70$ - to $80-(N=7)$ and 120-year-old trees $(N=5)$ were sampled for bark. The bark $(1.5 \times 12 \mathrm{~cm}$, about $6 \mathrm{~g}$ ) was taken from the southern side of the trunk at a height of 50-100 $\mathrm{cm}$ from the 10-year-old trees and a height of $180 \mathrm{~cm}$ from the 35 - to $40-, 70$ - to 80 -, and 120 -year-old trees, i.e. in the lower one-third of the trunk. Bark samples were transported in small hermetically sealed plastic bags and kept in the laboratory at $-18{ }^{\circ} \mathrm{C}$ until extraction.

\subsection{Bark sample extraction}

Norway spruce bark extracts were prepared by hydrodistillation: $5 \mathrm{~g}$ bark was cut into small pieces, soaked in water for $1 \mathrm{~h}$, and boiled in a Clevenger type apparatus for $2 \mathrm{~h}$ (Eur. Ph. 1996). Volatiles were collected into $3 \mathrm{~mL}$ of a mixture of hexane and diethyl ether (2:1). The extract was dried over $\mathrm{MgSO}_{4}$, filtered and stored in a freezer at $-18{ }^{\circ} \mathrm{C}$ until gas chromatographyelectroantennogram detection (GC-EAD) and gas chromatography-mass spectrometry (GC-MS) analyses. 


\subsection{Gas chromatography-electroantennogram detection}

For the GC-EAD analysis, bark extract from 40-year-old trees was used because trees become attractive to bark beetles starting from 40 years of age (see CFIA 2012). Bark extract $(1 \mu \mathrm{L})$ was injected splitlessly into a Clarus 500 gas chromatograph (PerkinElmer, Waltham, MA) equipped with a DB-Wax capillary column (30 m; $0.25 \mathrm{~mm}$ i.d., $0.25 \mu \mathrm{m}$ film-thickness, Agilent Technologies, Santa Clara, CA) and a 1:1 effluent splitter that allowed a simultaneous flame ionization detection (FID) and EAD of the separated volatile compounds. Hydrogen was used as carrier gas $(2.5 \mathrm{~mL} /$ min). The injector temperature as well as that of the detector was set at $240{ }^{\circ} \mathrm{C}$. The column temperature was maintained at $40{ }^{\circ} \mathrm{C}$ for $1 \mathrm{~min}$, after which it was raised to $200{ }^{\circ} \mathrm{C}$ at a rate of $5{ }^{\circ} \mathrm{C} / \mathrm{min}$, then increased to $240{ }^{\circ} \mathrm{C}$ at a rate of $10{ }^{\circ} \mathrm{C} / \mathrm{min}$, and maintained isothermally for $11 \mathrm{~min}$.

The outlet for the EAD was held in a humidified air-stream flowing at $0.5 \mathrm{~m} / \mathrm{s}$ over an I. typographus antennal preparation (Zhang et al. 2000). A glass capillary indifferent electrode filled with $0.9 \% \mathrm{NaCl}$ saline (Ilsanta, Vilnius, Lithuania) and grounded via a silver wire was inserted into the severed beetle head with antennae. A recording electrode connected to a high-impedance DC amplifier with automatic baseline drift compensation was placed in contact with the distal end of an antenna. The signal was stored and analysed on a PC equipped with an IDAC-card using the program GcEad V. 4.4 (Synthech, NL 1998). A total of 12 antennae from different males were used for the GC-EAD analysis.

\subsection{EAG dose-response}

Using the same electrophysiological recording setup and the same antennal preparation technique, electroantennogram (EAG) dose-responses of I. typographus males and females to synthetic trans-4-thujanol were recorded. Stimuli prepared by diluting the EAD-active compound in $10 \mu \mathrm{L}$ hexane were applied to a piece of filter paper $(5 \times 45 \mathrm{~mm})$ in a Pasteur pipette; four concentrations were tested in ascending order $\left(0.1,1,10\right.$, then $\left.10^{2} \mu \mathrm{g}\right)$. A solvent blank $(10 \mu \mathrm{L}$ hexane after evaporation) was tested as a control stimulus before the lowest and after the highest dosage of the test compound. We recorded the peak voltage amplitude during the puff delivery of each stimulus as an antennal response. Each stimulation was followed by a minimum of a 2-min purge period of filtered air to ensure recovery of antennal receptors. The EAG responses to EAD-active compound doses $(\mathrm{R})$ were calculated according to the formula: $R=R_{\mathrm{A}}-\left(R_{\mathrm{C} 1}+R_{\mathrm{C} 2}\right) / 2$, where $R_{\mathrm{A}}$ was the recorded EAG response to the EAD-active compound, and $R_{\mathrm{C} 1}$ and $R_{\mathrm{C} 2}$ were $\mathrm{EAG}$ responses to the first and the second control stimuli.

\subsection{GC-MS analysis}

Bark extracts were analysed using a Varian 3400 GC (Varian INC, Palo Alto, CA) connected to a Finnigan SSQ 7000 MS (Thermo-Finnigan, San Jose, CA) with a DB-WAX fused silica capillary column $(30 \mathrm{~m} ; 0.25 \mathrm{~mm}$ i.d., $0.25 \mu \mathrm{m}$ film-thickness, J\&W Scientific, Folsom, CA) and Shimadzu GC-MSQP2010 Plus (Shimadzu, Tokyo, Japan) with a Rxi-1 ms fused silica capillary column ( $30 \mathrm{~m}$; $0.25 \mathrm{~mm}$ i.d., $0.25 \mu \mathrm{m}$ film-thickness, Restek, Bellefonte, PA). The temperature was programmed as follows: the initial temperature of $40^{\circ} \mathrm{C}$ was kept for $1 \mathrm{~min}$, after which it was increased to $200^{\circ} \mathrm{C}$ at a rate of $5{ }^{\circ} \mathrm{C} / \mathrm{min}$, then raised to $230^{\circ} \mathrm{C}$ at a rate of $10^{\circ} \mathrm{C} / \mathrm{min}$, and maintained constant at $230^{\circ} \mathrm{C}$ for $23 \mathrm{~min}$. The injector temperature was $230{ }^{\circ} \mathrm{C}$. Helium was used as carrier gas (inlet pressure $70 \mathrm{kPa}$ ). Electron ionisation spectra were acquired at an electron energy of $70 \mathrm{eV}$, and the ion-trap source temperature was $150{ }^{\circ} \mathrm{C}$. The sample $(1 \mu \mathrm{L})$ was introduced to the injector manually. The compounds were identified by comparing retention indexes (RIs) and mass spectra with NIST (National Institute of Standards and Technology) reference libraries and with an authenticated standard (below).

\subsection{Isomer identification}

The synthetic standard of 4-thujanol (2-methyl-5-(1methylethyl)bicyclo[3.1.0]hexan-2-ol) (CAS Nr. 546-79-2) was obtained from Fluka (Seelze, Germany). Shimadzu GCMS-QP2010 Plus (Shimadzu) was used for GC-MS analyses of the 4-thujanol standard on a non-polar (RI 1052, Rxi-1 ms) and a polar (RI 1465, DB-Wax) column to identify the isomer. The temperature was programmed as described above. The structure of the compound was confirmed by nuclear magnetic spectroscopy (NMR). The NMR data were obtained using Bruker DRX-400 NMR instrument equipped with a $5 \mathrm{~mm}$ inverse broadband probe head. The 2D NMR experiments (COSY, NOESY, HMQC) were measured by running standard Bruker pulse sequences at room temperature.

\subsection{Y-tube olfactometer bioassays}

Olfactory responses of I. typographus adults in pedestrian bioassays were tested using a Y-tube olfactometer modified from Schlyter and Löfqvist (1986). The Ytube olfactometer consisted of the following parts: a release chamber, a Y-tube (internal diameter $0.7 \mathrm{~cm}$; length of arms $4 \mathrm{~cm})$, a beetle trap $(10 \mathrm{~mL}$ vials on each arm of the olfactometer), and a stimulus-holding tube containing a piece of filter paper $(5 \times 45 \mathrm{~mm})$ with stimuli (also on each arm of the olfactometer). Filtered, humidified air $(1.6 \mathrm{~mL} / \mathrm{s})$ carried odours from the two stimulus-holding tubes to each arm of the Y-tube. 
Solutions of $200 \mathrm{mg} / \mathrm{mL}$ and $20 \mathrm{mg} / \mathrm{mL}$ of synthetic trans4-thujanol in hexane (for $\mathrm{GC} \geq 99.0 \%$, Fluka) were prepared and $10 \mu \mathrm{L}$ sample was then applied to filter paper squares, giving doses of $20 \mu \mathrm{g}$ and $200 \mu \mathrm{g}$, respectively. The solvent was allowed to evaporate for $20 \mathrm{~s}$ before the papers were placed inside the sample tubes. Ten microlitres of hexane after evaporation was used as a control.

An hour before the test, the sexed beetles were placed in Petri dishes. About 35 (range 30-40) beetles of each sex were used in each test. A dose of 20 or $200 \mu \mathrm{g}$ trans-4-thujanol was tested using three and four replicates on females, four and six replicates on males, respectively. Three replicates were used for control.

The same beetles were tested once a day for 2 days and each test lasted $1 \mathrm{~h}$. At the end of the test, beetles in different parts of the apparatus were counted. The individuals collected in a trap were recorded as responding to either the test odour or the control depending on the arm of olfactometer chosen. After each test, approximately $20 \%$ of the beetles remained in the release chamber or in the first part of the Y-tube, having not responded to either of the stimuli. These beetles were excluded from data analysis. Between trials, we replaced Y-tubes with clean ones and swapped bait treatments to opposite arms to eliminate directional bias.

\subsection{Statistical analysis}

Statistical analysis was performed using Statistica 6.0 software (StatSoft, Tulsa, OK). The Wilcoxon paired signed rank test was used to compare antennal responses to EAD-active compound dilutions to the average of the contiguous control responses. Detection thresholds were determined as the lowest concentration at which compounds elicited significantly larger responses than those of the control. EAG amplitudes of beetle antennae of both sexes were compared using a Mann-Whitney U test.

A $G$-test for goodness-of-fit was used to identify significant preferences for one olfactometer branch in the Y-tube tests (Sokal and Rohlf 1995). We set the $\alpha$ level at 0.05 for all tests.

The absolute amount of trans-4-thujanol was calculated relative to the internal standard (tetradecane) and expressed as an equivalent ( $\mu \mathrm{g} / \mathrm{g}$ dry $\mathrm{wt})$. The relative amount of trans4-thujanol was calculated as the ratio of the area of its GC peak to the sum of all areas of the 13 monoterpene hydrocarbons in a defined GC fraction consisting of compounds eluting at RI from 998 to 1275 (see Table 1), and expressed as percentage.

The Spearman nonparametric correlation $\left(R_{\mathrm{S}}\right)$ was used to determine the relationship between the age of Norway spruce trees and either the absolute or relative amount of trans-4thujanol produced by the trees.

\section{Results}

\subsection{GC-EAD recordings and GC-MS analysis}

GC-EAD results demonstrated that extracts of spruce bark contained compounds that elicited antennal responses from bark beetles. One EAD-active compound (recorded in 10 of 12 runs, labelled 4 in Fig. 1) showed a mass spectrum very similar to that of trans-4-thujanol. The elution data of the natural product from polar and non-polar capillary columns closely matched those of the synthetic standard (Fig. 2). In conclusion, the EAD active compound present in Norway spruce bark extract was identified as trans-4-thujanol. The identity of five other EAD-active compounds remains tentative and additional experiments are ongoing.

\subsection{GC-MS and NMR spectroscopy analyses of standards}

GC-MS analyses of the 4-thujanol standard based on its GC retention index on a non-polar (RI 1052, Rxi-1 ms) and a polar (RI 1465, DB-Wax) column showed trans-4-thujanol isomer (trans- for Me vs. IPP) (after Adams 2012; Umano et al. 2002) (Fig. 2).

The structure of the compound was confirmed by NMR spectroscopy. The one and two-dimensional ${ }^{1} \mathrm{H}$ and ${ }^{13} \mathrm{C}$ NMR spectra proved the trans-structure unambiguously. In the ${ }^{1} \mathrm{H}-{ }^{1} \mathrm{H}$ 2D NOESY experiment, strong cross peaks appeared between the 10-methyl protons and the proton in position 1 and one of the methylene protons in position 6 (circled in the NOESY spectrum in Fig. 3a) indicating their steric proximity (arrows in Fig. 3b). The distance between the methyl protons and the corresponding methylene proton in position 6 (circles in Fig. 3c) in the cis- isomer is much larger and out of the range of the distance (ca. $4 \AA$ ) for a NOE observation.

\subsection{EAG dose-response}

EAG analysis of synthetic trans-4-thujanol confirmed the consistent response of bark beetle antennae. The EAG doseresponses to trans-4-thujanol indicated that the elicitation in bark beetles was not strong; the mean antennal response of male beetles varied from $0.028 \pm 0.003 \mathrm{mV}$ at the lowest dose $(0.1 \mu \mathrm{g})$ to $0.078 \pm 0.006 \mathrm{mV}$ at the highest dose $(100 \mu \mathrm{g})$. Meanwhile, the mean antennal response of females varied from $0.05 \pm 0.003 \mathrm{mV}$ to $0.062 \pm 0.005 \mathrm{mV}$, respectively. A statistically significant difference in responses to $0.1 \mu \mathrm{g}$ trans4-thujanol was recorded between male and female beetles (Fig. 4), with males responding more weakly than females (Mann-Whitney $U$ test; $U=52, P=0.03$ ).

The threshold dose of trans-4-thujanol that elicited a significantly stronger antennal response than the control was 
Table 1 Amount of terpenes (\%, mean \pm standard error) in bark of Norway spruce (Picea abies) of different age

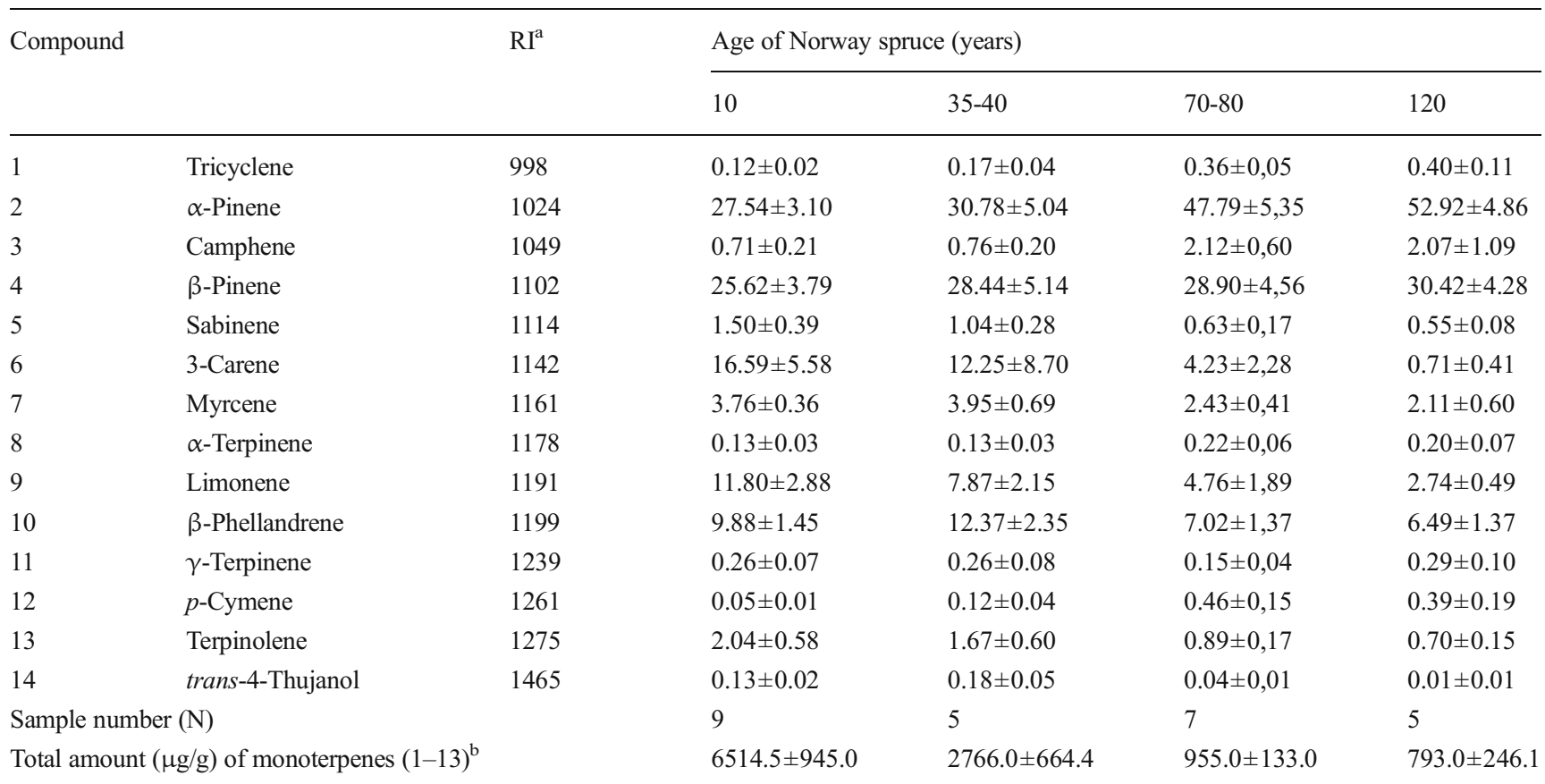

${ }^{\mathrm{a}} \mathrm{RI}$ calculated from retention times relative to that of n-alkanes (C10-C33 on the polar DB-Wax column)

${ }^{\mathrm{b}}$ Dry weight of bark

$1 \mu \mathrm{g}$ (Wilcoxon test; $Z=2.95, P=0.003$ ) for males, and $0.1 \mu \mathrm{g}$ $(Z=2.20, P=0.028)$ for females.

\subsection{Y-tube olfactometer bioassays}

The control bioassay during which the same control stimulus (10 $\mu \mathrm{L}$ hexane after evaporation) was delivered to both branches of the Y-tube olfactometer showed that both females and males selected either branches of the olfactometer equally (males: $G=0.89, P>0.05$; females: $G=0.61, P>0.05$ ). When bark beetles were allowed to choose between $20 \mu \mathrm{g}$ trans-4thujanol and the control, neither sex demonstrated a preference (males: $G=0.22, P>0.05$; females: $G=0.82$, $P>0.05$ ). However, a ten-fold increase in the dose of trans4-thujanol caused a significant preference of control versus monoterpene sample in both male $(G=4.6, P=0.032)$ and female $(G=11.6, P<0.001)$ bark beetles (Fig. 5). In conclusion, trans-4-thujanol at a dose of $200 \mu \mathrm{g}$ acted as repellent to the bark beetles tested.

\subsection{Trans-4-thujanol in host plant}

The amount of trans-4-thujanol in spruce tree bark extracts was tree age dependent. On average, the amount extracted

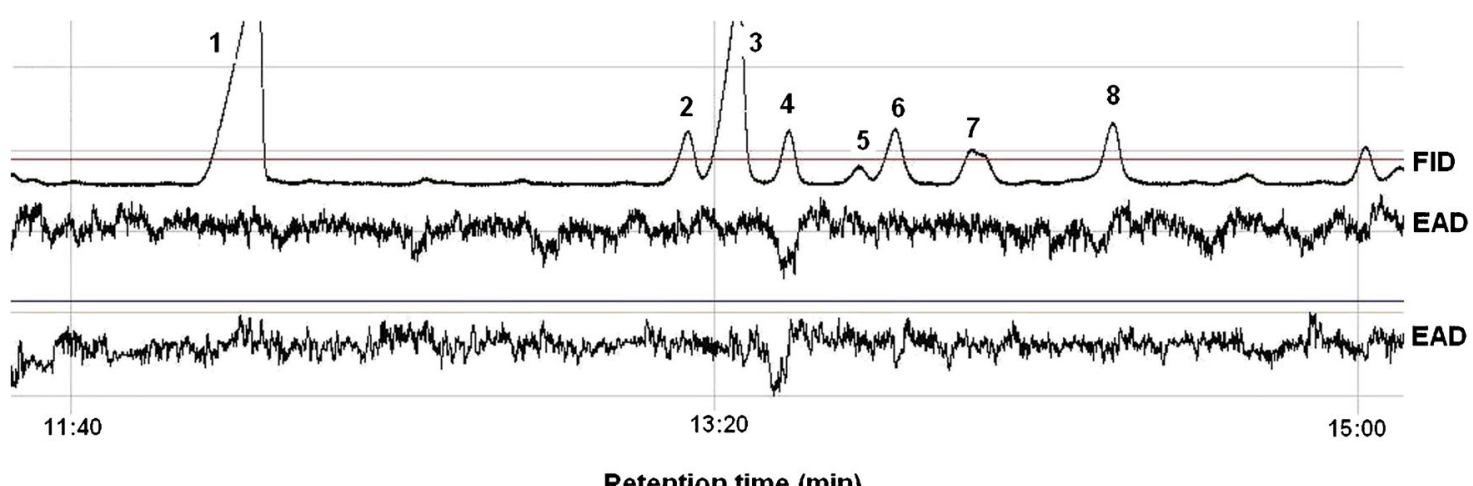

Retention time (min)

Fig. 1 Flame-ionization (FID) and electroantennogram detector (EAD) recordings of antennal responses of Ips typographus males to Norway spruce bark extract. 1 Internal standard (tetradecane); $2 \alpha$-longipinene; 3 cyclosativene; 4 trans-4-thujanol; 5 ylangene; 6 copaene; 7, 8 unidentified 
Fig. 2 Parts of chromatograms of Norway spruce bark extract $(c)$ and trans-4-thujanol standard (d) on a non-polar column Rxi-1 ms, and $\mathbf{b}$ polar column DB-Wax. 1 Limonene; $2 \gamma$-terpinene; 3 trans4-thujanol; 4 terpinolene; 5 cis-4thujanol; $6 \alpha$-longipinene; 7 cyclosativene; 8 ylangene; 9 copaene; 10,11 unidentified

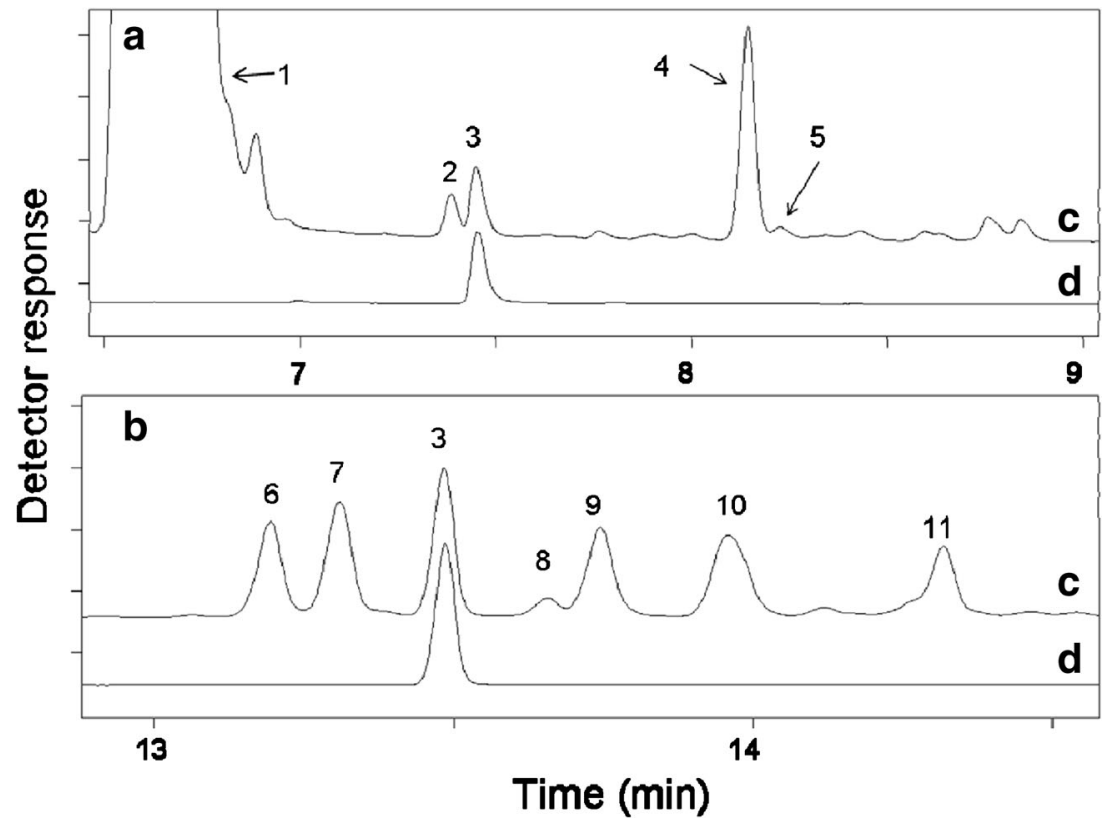

from 10-year-old spruce trees $(18.1 \pm 2.4 \mu \mathrm{g} / \mathrm{g})$ was 3 times higher than in 35- to 40 -year-old trees $(5.6 \pm 1.4 \mu \mathrm{g} / \mathrm{g}), 27$ times higher than in 70 - to 80 -year-old trees $(0.7 \pm 0.3 \mu \mathrm{g} / \mathrm{g})$, and 200 times higher than in 120-year-old trees $(0.09 \pm$ $0.05 \mu \mathrm{g} / \mathrm{g}$ ). Both absolute and relative amounts of trans-4thujanol in the bark of spruce trees negatively correlated to tree age (absolute amount: $R_{S}=-0.89, P<0.001$; relative amount: $R_{S}=-0.72, P<0.001$ ) (Fig. 6).

\section{Discussion}

The electrophysiological response data of bark beetle antennae to volatiles produced by the host plant revealed the ability of I. typographus to perceive compounds present in spruce bark. Using the GC-MS method, one such compound was identified as trans-4-thujanol. Although this compound has been detected in the bark of Norway spruce (Schiebe 2012) and in volatiles collected from I. typographus males boring in spruce (Francke et al. 1995), no functional evidence of the compound has been reported. Some data on I. typographus EAG-active compounds, including trans-4-thujanol, have been presented previously (Blažytė-Čereškienè et al. 2009; Schiebe 2012), but here we report for the first time a behavioural effect of this compound, and the correlation between trans-4-thujanol amount and tree age.

The mere fact that bark beetles react to trans-4-thujanol at both the receptor and behavioural levels indicates the potential importance of this compound. Despite trans-4-thujanol being repellent for bark beetles under laboratory conditions, it remains to be investigated whether it is active in the field. We assume that this compound belongs to the group of already known substances decreasing attraction of I. typographus adults, including 1,8-cineole and (-)-limonene both produced by spruce trees (Andersson et al. 2010; Schiebe et al. 2012), verbenone released by microorganisms in the galleries of bark beetles (review in Byers 2004) and green leaf volatiles emitted by many non-host trees (Zhang et al. 1999), as well as ipsenol and ipsdienol produced by I. typographus males to avoid competition in the later phases of tree attack (Birgersson et al. 1988).

Our results raise a question about the actual emission rates of trans-4-thujanol from spruce tree bark in nature. To address this, solid phase microextraction (SPME) or another technique for volatile collection would help determine the concentration of trans-4-thujanol in the vicinity of a trunk. It thus remains to be investigated whether this concentration of trans-4-thujanol is sufficient to induce behavioural reactions and to affect spruce tree selection by beetles.

Interestingly, the EAG dose-response recordings revealed some sexual differences in sensitivity: at low dosages, trans-4thujanol induced higher EAG amplitudes in the antennae of I. typographus females than in those of males (Fig. 4). This may indicate that female antennae contain more receptor cells that respond to this compound, supporting the data obtained by single-cell activity recordings that showed that females contain a higher proportion of receptor neurones tuned for compounds of host-plant origin than do males (Andersson et al. 2009). I. typographus attacks many more spruce trees than those that become successfully colonised and subsequently killed (e.g. Schiebe et al. 2012). Spruce tree attack is initiated by pioneer males selecting the tree, excavating a short nuptial chamber and starting pheromone release. In the case of unsuccessful attack, the pioneer beetles either drowned in 
Fig. 3 a ${ }^{1} \mathrm{H}-{ }^{1} \mathrm{H} 2 \mathrm{D}$ NOESY spectrum of trans-4-thujanol. b, c Geometry optimized structures for trans- (b) and cis- (c) 4thujanol

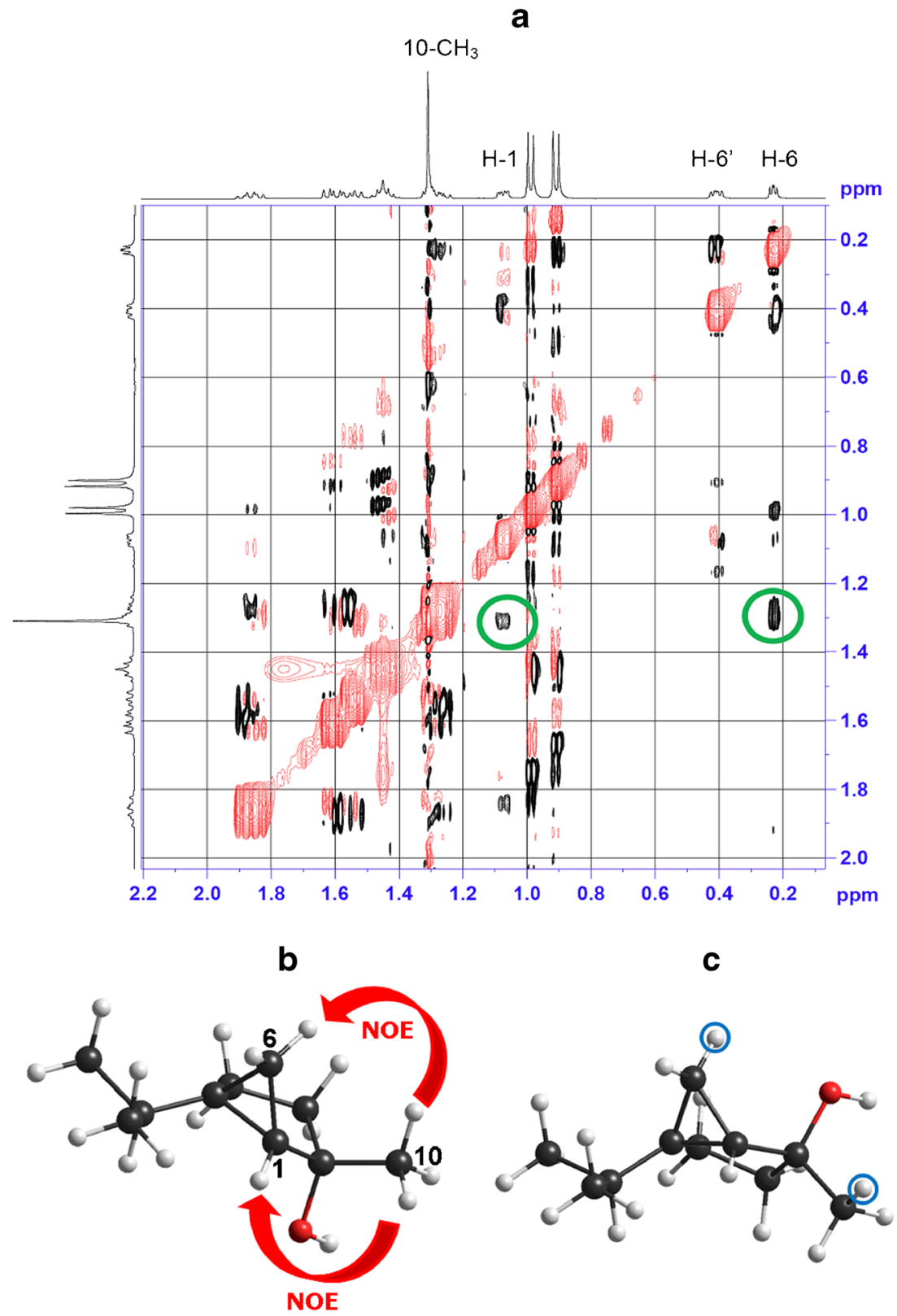

resin or had left their entrance holes after 3 days when no further beetles joined their attack (Schiebe et al. 2012). It remains unclear why conspecifics sometimes do not join the attack. During the early attack phase nearly $60 \%$ of arriving females either fly away or drop down from the tree already settled by pioneer males (Paynter et al. 1990). One may assume that input from females joining pioneer males is important in the success of an attack, especially keeping in mind that females join the attack shortly after the pioneer males start producing and releasing aggregation pheromone, i.e. during the initial phase of the attack (from few hours to1 day, Schlyter et al. 1987). In addition, females have higher tunnelling activity than males (Faccoli and Schlyter 2007), and are more abundant in colonised trees than males (Wermelinger 2004). Tree resistance decreases as phloem infestation increases (Lieutier 2004), and females contribute significantly to this process by boring egg-galleries (Faccoli and Schlyter 2007). If females do not make the galleries, the tree might survive the pioneers' attack. The involvement of females in the exhaustion of tree defences is under debate (Faccoli and Schlyter 2007; Lieutier et al. 2009). However, it could be hypothesized that, if the females are more sensitive to trans-4-thujanol than males, they could reject some trees already selected by pioneer males, thus decreasing the chance of a successful attack. Double choice may increase the probability of colonising only the most suitable trees. 


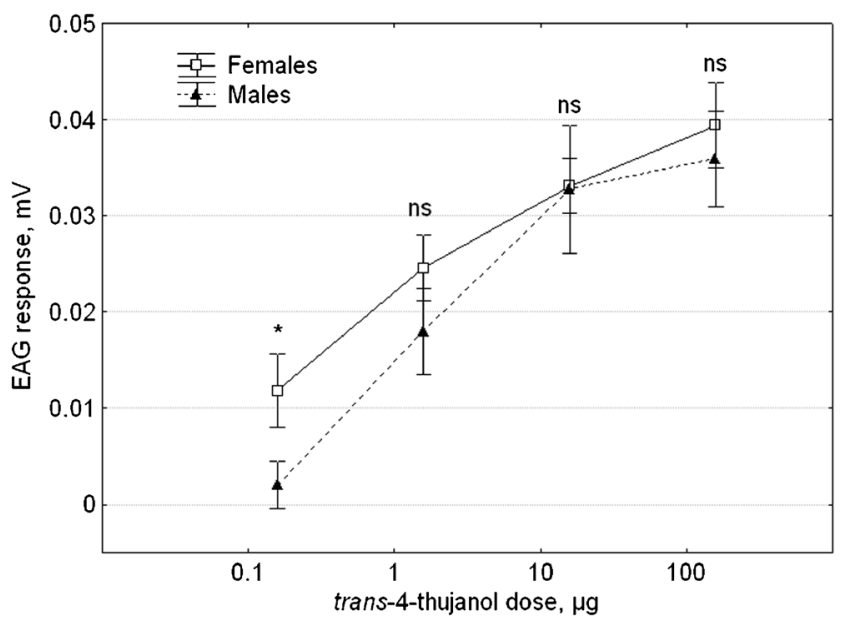

Fig. 4 Electroantennogram (EAG; mean amplitude \pm SE) doseresponses of I. typographus antennae to trans-4-thujanol. Asterisk indicates a significant difference between EAG responses of males and females (Mann-Whitney $U$ test; $P<0.05$ )

As suitable spruce choice by females determines offspring survival, selection of a correct location for egg-laying is critical for progeny. We assume that the repellent properties of trans-4thujanol might be involved in the process. Moreover, the compound is not specific to the spruce tree, as trans-4-thujanol is present in many plant species and especially abundant in those of medicinal importance (e.g. Groendahl et al. 2008; Novak et al. 2000), and which are well known for their fungicidal properties. For instance, essential oil of marjoram contains trans-4-thujanol as one of the main components (Novak et al. 2000), and the oil acts as a fungicide (Sharma et al. 2011). We assume that trans-4-thujanol may have an antifungal property, like some Norway spruce monoterpenes, which can inhibit

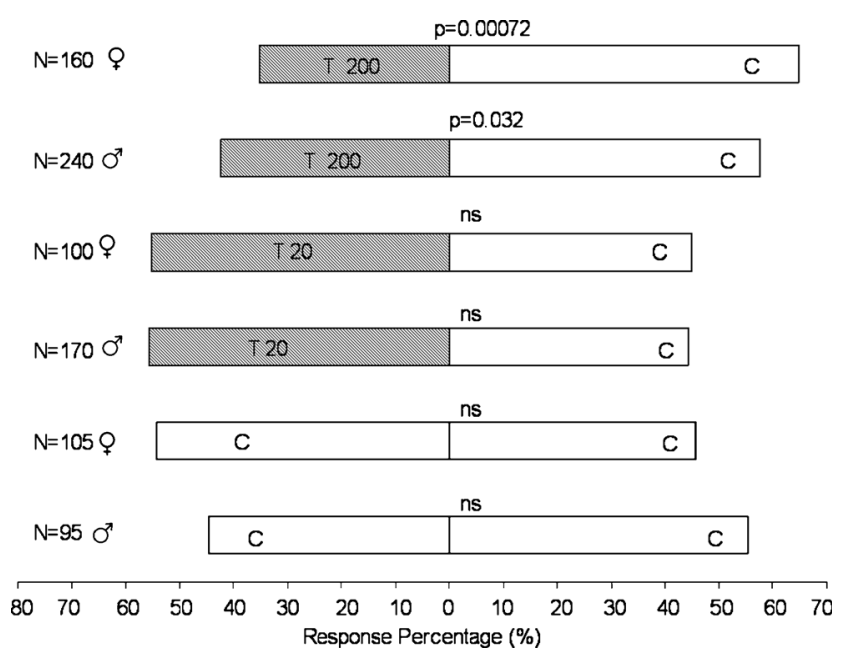

Fig. 5 Behavioural response of I. typographus beetles in paired choice test using a Y-tube olfactometer. $T$ Choice of trans-4-thujanol (doses $20 \mu \mathrm{g}$ and $200 \mu \mathrm{g}), C$ choice of control $(10 \mu \mathrm{L}$ evaporated hexane). The difference in response was calculated using $G$-test; $n s$ no significant difference
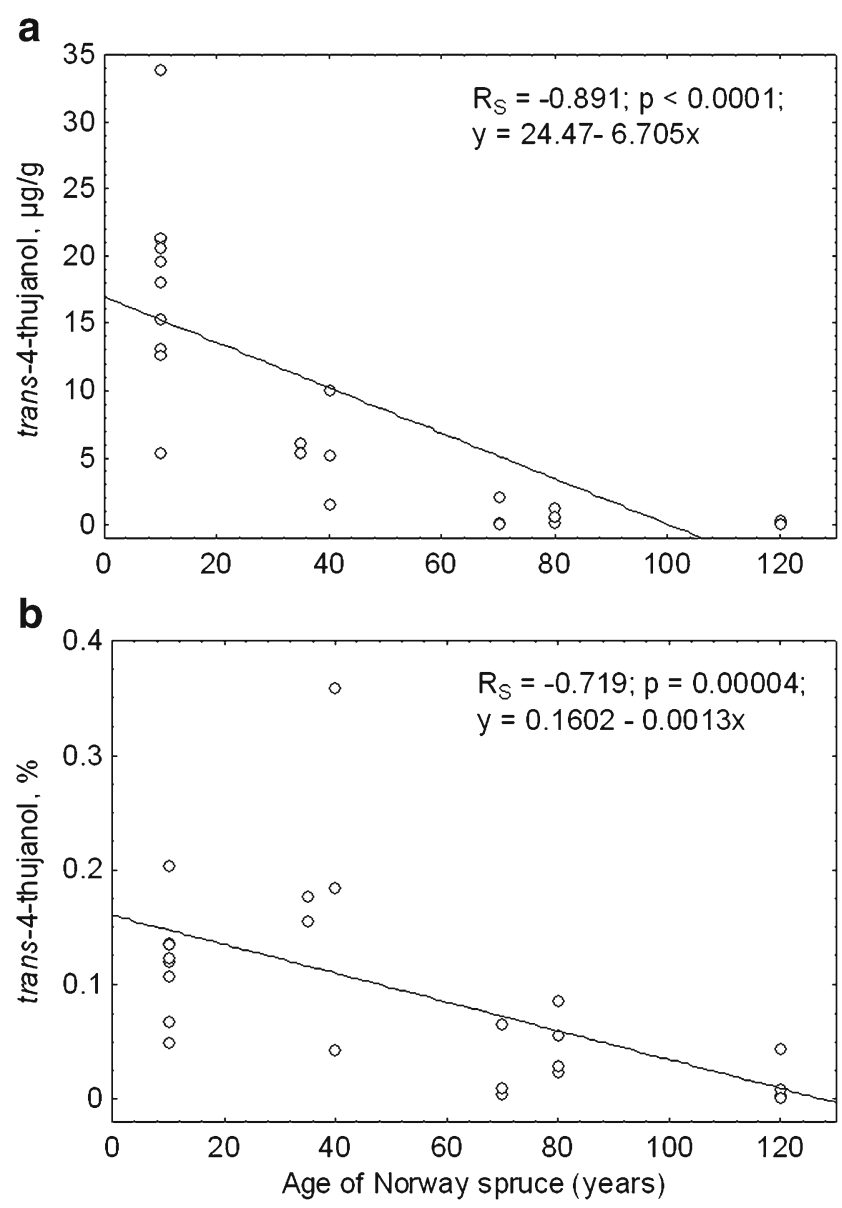

Fig. 6 Relationship between Norway spruce age and a the concentration $(\mu \mathrm{g} / \mathrm{g}$ dry weight of bark) as well as $\mathbf{b}$ the relative amount ( $\%$, in relation to 13 monoterpenes) of trans-4-thujanol

growth of the blue stain fungus, Ceratocystis polonica (Siem) C. Moreau (Novak et al. 2014). As fungi within galleries excavated by bark beetles are important for I. typographus larval feeding (Lieutier et al. 2009), the presence of a certain concentration of trans-4-thujanol might be unfavourable for bark beetle broods. Thus, the females' higher sensitivity to the repellent compound trans-4-thujanol might ensure selection of the most suitable locations for egg-laying.

It is well known that ageing spruce trees become predisposed to bark beetle infestation (e.g. Grodzki et al. 2014; Netherer and Nopp-Mayr 2005). When trees are less than 40 years old, spruce stands sustain very little damage (CFIA 2012), but tree mortality caused by bark beetle attack increases when stands are older than 50-60 years (Grodzki et al. 2006). Our results indicate that the concentration of trans-4-thujanol decreases in ageing spruce trees, and does so alongside the concentration of other closely related secondary metabolites, i.e. monoterpenes (Table 1). Thus, the emission of trans-4-thujanol might allow I. typographus to discriminate suitable and/or older trees. To compare our results with those obtained by other authors on bark chemistry 
dynamics in ageing spruce trees is hardly possible becuase, to our knowledge, no similar data have been published other than the well documented dynamics of ageing seedlings (Kännaste et al. 2013).

In summary, our results show that trans-4-thujanol produced by spruce trees triggers a behavioural response in I. typographus. Laboratory bioassay revealed the repellent properties of the compound. The data presented in this paper raises questions regarding whether trans-4-thujanol affects bark beetle behaviour in the field, which could be useful in integrated forest protection against bark beetles, and whether the compound may reflect substrate quality for brood development. Further experiments would be required to test these hypotheses.

\begin{abstract}
Acknowledgements We thank the officers of the Trakai and Sužionys forestries (Lithuania) for permission to collect beetles from traps, and for assistance in collecting bark samples from Norway spruce trees of different age, as well as Ms. Laima Monkiene and Mr Jos Stratford for English text correction. We also acknowledge Assoc. Prof. Zoltan Szabo at the Department of Chemistry at the Royal Institute of Technology, Stockholm for running NMR experiments and processing data, and the anonymous reviewers and handling editor for comments on previous drafts of the manuscript. Open Access to research infrastructure of the Nature Research Centre under Lithuanian open access network initiative is acknowledged.
\end{abstract}

Funding This study was supported by the Research Council of Lithuania, Contract No MIP-86/2010.

Open Access This article is distributed under the terms of the Creative Commons Attribution 4.0 International License (http:// creativecommons.org/licenses/by/4.0/), which permits unrestricted use, distribution, and reproduction in any medium, provided you give appropriate credit to the original author(s) and the source, provide a link to the Creative Commons license, and indicate if changes were made.

\section{References}

Adams RP (2012) Identification of essential oil components by gas chromatography / mass spectrometry, 4th edn. Allured Business Media, Carol Stream, IL

Andersson MN (2012) Mechanisms of odor coding in coniferous bark beetles: from neuron to behavior and application. Psiche. doi:10. 1155/2012/149572, Article ID 149572

Andersson MN, Larsson MC, Schlyter F (2009) Specificity and redundancy in the olfactory system of the bark beetle Ips typographus: single-cell responses to ecologically relevant odors. J Insect Physiol 55:556-567. doi:10.1016/j.jinsphys.2009.01.018

Andersson MN, Larsson MC, Blaženec M, Jakuš R, Zhang Q-H, Schlyter F (2010) Peripheral modulation of pheromone response by inhibitory host compound in a beetle. J Exp Biol 213:3332-3339. doi:10. $1242 / \mathrm{jeb} .044396$

Becker T, Schröter H (2000) Ausbreitung von rindenbrütenden Borkenkäfern nach Sturmschäden. Allg Forstztg 55:280-282

Birgersson G, Schlyter F, Bergström G, Löfqvist J (1988) Individual variation in aggregation pheromone content of the bark beetle, Ips typographus. J Chem Ecol 14:1737-1761. doi:10.1007/ BF01014641
Blažytė-Čereškienė L, Vaitkevičienė G, Apšegaitè V, Karalius V, Būda V (2009) Norway spruce (Picea abies) and bark beetle (Ips typographus): search for attractiveness antagonist(s) of plant origin. 25th Annual meeting of Chemical Ecology. 23-27 August 2009, Neuchatel, p 232

Byers JA (1989) Chemical ecology of bark beetles. Experientia 45:271283. doi:10.1007/BF01951813

Byers JA (2004) Chemical ecology of bark beetles in a complex olfactory landscape. In: Lieutier F, Day KR, Battisti AJ, Grégoire C, Evans HF (eds) Bark and wood boring insects in living trees in Europe, a synthesis. Kluwer, Dordrecht, pp 89-34

Canadian Food Inspection Agency (CFIA) (2012) Ips typographus (European Spruce Bark Beetle) - fact sheet. http://www.inspection. gc.ca/plants/plant-protection/insects/european-spruce-bark-beetle/ fact-sheet/eng/1327356236249/1327365288030. Accessed 23 February 2015

Erbilgin N, Kokene P, Kvamme T, Christiansen E (2007) A host monoterpene influences Ips typographus (Coleoptera, Scolytidae) responses to its aggregation pheromone. Agric For Entomol 9:135140. doi:10.1111/j.1461-9563.2007.00329.x

Faccoli M, Schlyter F (2007) Conifer phenolic resistance markers are bark beetle antifeedant semiochemicals. Agric For Entomol 9:237245. doi:10.1111/j.1461-9563.2007.00339.x

Francke W, Bartels J, Meyer H, Schröder F, Kohnle U, Baader E, Vité JP (1995) Semiochemicals from bark beetles: new results, remarks, and reflections. J Chem Ecol 21:1043-1063. doi:10.1007/BF02033807

Grodzki W, Jakuš R, Lajzová E, Sitková Z, Maczka T, Škvarenina J (2006) Effects of intensive versus no management strategies during an outbreak of the bark beetle Ips typographus (L.) (Col.: Curculionidae, Scolytinae) in the Tatra Mts. in Poland and Slovakia. Ann For Sci 63:55-61. doi:10.1051/forest:2005097

Grodzki W, Starzyk JR, Kosibowicz M (2014) Impact of stand characteristics on the occurrence of the bark beetle Ips typographus (L.) in the Beskid Zywiecki Mauntains. Leśne Prace Badawcze 75:159 169. doi:10.2478/frp-2014-0015

Groendahl E, Ehlers BK, Keefover-Ring K (2008) A new cis-sabinene hydrate chemotype detected in large thyme (Thymus pulegioides L.) growing wild in Denmark. J Essent Oil Res 20:40-41. doi:10.1080/ 10412905.2008.9699417

Jakuš R, Blaženec M (2003) Influence of the proportion of (-)- $\alpha$-pinene in pheromone bait on Ips typographus (Col., Scolytidae) catch in pheromone trap barriers and in single traps. J Appl Entomol 127:9195. doi:10.1045/j.1439-0418.2003.00695.x

Kalinová B, Břizová R, Knížek M, Turčáni M, Haskovec M (2014) Volatiles from spruce trap-trees detected by Ips typographus bark beetles: chemical and electrophysiological analyses. Arthropod Plant Interact 8:305-316. doi:10.1007/s11829-014-9310-7

Kännaste A, Zhao T, Lindstrom A, Stattin E, Langstrom B, Borg-Karlson AK (2013) Odors of Norway spruce (Picea abies L.) seedlings: differences due to age and chemotype. Trees 27:149-159. doi:10. 1007/s00468-012-0783-7

Landolt PJ, Phillips TW (1997) Host plant influences on sex pheromone behavior of phytophagous insects. Annu Rev Entomol 42:371-391. doi:10.1007/BF01256549

Långström B, Lindelöw Å, Schroeder LM, Björklund N, Öhrn P (2009) The spruce bark beetle outbreak in Sweden following the Januarystorms in 2005 and 2007. In: Kunca A, Zubrik M (eds) Insects and fungi in storm areas. Proceedings of the IUFRO Working Party 7.03.10 Methodology of forest insect and disease survey in Central Europe from the workshop that took place on September 15 to 19 , 2008 in Štrbské Pleso, Slovakia, p 13-19

Lieutier F (2004) Host resistance to bark beetles and its variations. In: Lieutier F, Day KR, Battisti A, Grégoire J-C, Evans HF (eds) Bark and wood boring insects in living trees in Europe, a synthesis. Kluwer, Dordrecht, pp 135-180 
Lieutier F, Yart A, Salle A (2009) Stimulation of tree defenses by ophiostomatoid fungi can explain attack success of bark beetles on conifers. Ann For Sci 66:801. doi:10.1051/forest/2009066

Mezei P, Grodzki W, Blaženec M, Jakuš R (2014) Factors influencing the wind-bark beetles' disturbance system in the course of an Ips typographus outbreak in the Tatra Mountains. For Ecol Manag 312:67-77. doi:10.1016/j.foreco.2013.10.020

Netherer S, Nopp-Mayr U (2005) Predisposition assessment systems (PAS) as supportive tools in forest management - rating of site and standrelated hazards of bark beetle infestation in the High Tatra Mountains as an example for system application and verification. For Ecol Manag 207:99-107. doi:10.1016/j.foreco.2004.10.020

Novak J, Bitsch C, Langbehn J, Pank F, Skoula M, Gotsiou Y, Franz CM (2000) Ratios of cis- and trans-sabinene hydrate in Origanum majorana L. and Origanum microphyllum (Bentham) Vogel. Biochem Syst Ecol 28:697-704. doi:10.1016/S0305-1978(99) 00098-8

Novak M, Krajnc AU, Lah L, Zupanec N, Kraševec N, Križman M, Bohlmann J, Komel R (2014) Low-density Ceratocystis polonica inoculation of Norway spruce (Picea abies) triggers accumulation of monoterpenes with antifungal properties. Eur J For Res 133:573583. doi:10.1007/s10342-013-0772-4

Paynter QE, Anderbrant O, Schlyter F (1990) Behavior of male and female spruce bark beetles, Ips typographus, on the bark of host trees. J Insect Behav 3:529-543. doi:10.1007/BF01052016

Schiebe C (2012) Attraction and resistance in the Picea abies-Ips typographus system. Host choice in the Eurasian spruce bark beetle. Doctoral Thesis. Swedish University of Agricultural Sciences, Alnarp

Schiebe C, Hammerbacher A, Birgersson G, Witzell J, Brodelius P, Gershenzon J, Hansson B, Krokene P, Schlyter F (2012) Inducibility of chemical defences in Norway spruce bark is correlated with unsuccessful mass attacks by the spruce bark beetle. Oecologia 170:183-198. doi:10.1007/s00442-012-2298-8

Schlyter F, Cederholm I (1981) Separation of the sexes of living spruce bark beetle, Ips typographus (L.) (Coleoptera: Scolytidae). Z Angew Entomol 92:42-47. doi:10.1111/j.1439-0418.1981.tb01650.x
Schlyter F, Löfqvist J (1986) Response of walking spruce bark beetles Ips typographus to pheromone produced in different attack phases. Entomol Exp Appl 41:219-230. doi:10.1111/j.1570-7458.1986. tb00532.x

Schlyter F, Löfqvist J, Byers JA (1987b) Behavioural sequence in attraction of the bark beetle Ips typogra- phus to pheromone sources. Physiol Entomol 12:185-196

Sharma N, Dubey NK, Sharma K (2011) Screening of insecticidal and antifungal activity of Origanum majorana oil against Callosobruchus chinensis (L.) and Aspergillus spp. Res J Agric Biol Sci 7:223-227

Sokal RR, Rohlf FJ (1995) Biometry, 3rd edn. Freeman, New York

Umano K, Yukio H, Takayuki S (2002) Volatile chemicals identified in extracts from newly hybrid citrus, Dekopon (Shiranuhi mandarin). Suppl J Agric Food Chem 50:5355-5535. doi:10.1021/jf0203951

Wermelinger B (2004) Ecology and management of the spruce bark beetle Ips typographus - a review of recent research. For Ecol Manag 202:67-82. doi:10.1016/j.foreco.2004.07.018

Zhang Q-H, Schlyter F (2003) Redundancy, synergism, and active inhibitory range of non-host volatiles in reducing pheromone attraction in European spruce bark beetle Ips typographus. Oikos 101:299-310. doi:10.1007/s00049-003-0261-1

Zhang Q-H, Schlyter F (2004) Olfactory recognition and behavioural avoidance of angiosperm nonhost volatiles by conifer-inhabiting bark beetles. Agric For Entomol 6:1-19. doi:10.1111/j.1461-9555. 2004.00202.x

Zhang QH, Schlyter F, Anderson P (1999) Green leaf volatiles interrupt pheromone response of spruce bark beetle, Ips typographus. J Chem Ecol 25:2847-2861. doi:10.1023/A:1020816011131

Zhang Q-H, Schlyter F, Birgersson G (2000) Bark volatiles from nonhost angiosperm trees of spruce bark beetle, Ips typographus (L.) (Coleoptera: Scolytidae): chemical and electrophysiological analysis. Chemoecology 10:69-80. doi:10.1007/s000490050010

Zolubas P, Negron J, Munson AS (2009) Modelling spruce bark beetle infestation probability. Baltic For 15:23-27 